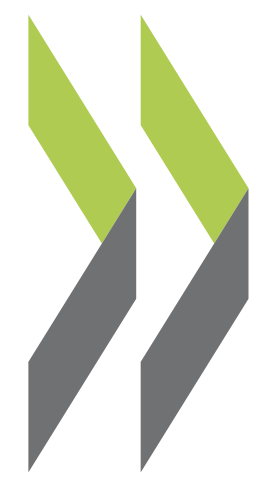

OECD Economics Department Working Papers No. 1440

$$
\begin{array}{r}
\text { The fiscal projection } \\
\text { framework in long-term } \\
\text { scenarios }
\end{array}
$$

Yvan Guillemette, David Turner 
Organisation de Coopération et de Développement Économiques

Organisation for Economic Co-operation and Development

27-Nov-2017

ECONOMICS DEPARTMENT

English - Or. English

THE FISCAL PROJECTION FRAMEWORK IN LONG-TERM SCENARIOS

ECONOMICS DEPARTMENT WORKING PAPERS No. 1440

By Yvan Guillemette and David Turner

OECD Working Papers should not be reported as representing the official views of the OECD or of its member countries. The opinions expressed and arguments employed are those of the author(s).

Authorised for publication by Christian Kastrop, Director, Policy Studies Branch, Economics Department.

All Economics Department Working Papers are available at www.oecd.org/eco/workingpapers.

JT03423641

This document, as well as any data and map included herein, are without prejudice to the status of or sovereignty over any territory, to the delimitation of international frontiers and boundaries and to the name of any territory, city or area. 
OECD Working Papers should not be reported as representing the official views of the OECD or of its member countries. The opinions expressed and arguments employed are those of the author(s).

Working Papers describe preliminary results or research in progress by the author(s) and are published to stimulate discussion on a broad range of issues on which the OECD works.

Comments on Working Papers are welcomed, and may be sent to OECD Economics Department, 2 rue André Pascal, 75775 Paris Cedex 16, France, or by e-mail to eco.contact@oecd.org.

All Economics Department Working Papers are available at www.oecd.org/eco/workingpapers.

This document and any map included herein are without prejudice to the status of or sovereignty over any territory, to the delimitation of international frontiers and boundaries and to the name of any territory, city or area.

The statistical data for Israel are supplied by and under the responsibility of the relevant Israeli authorities. The use of such data by the OECD is without prejudice to the status of the Golan Heights, East Jerusalem and Israeli settlements in the West Bank under the terms of international law.

\section{(C) OECD (2017)}

You can copy, download or print OECD content for your own use, and you can include excerpts from OECD publications, databases and multimedia products in your own documents, presentations, blogs, websites and teaching materials, provided that suitable acknowledgment of OECD as source and copyright owner is given. All requests for commercial use and translation rights should be submitted to rights@oecd.org 


\section{ABSTRACT/RÉSUMÉ \\ The fiscal projection framework in long-term scenarios}

The paper describes the fiscal framework used in long-term economic scenarios, with some emphasis on revisions made since the 2013 vintage of the long-term model. Long-term projections for public spending on pensions, health and long-term care are now separate from other primary expenditure and sourced from previous OECD work taking account of population ageing and other cost pressures. Other primary expenditure are assumed to remain constant in real terms on a per capita basis, rather than remaining stable as a share of GDP. This difference is important for long-term fiscal projections because government finances are sensitive to the employment rate, whereas expenditure is linked to the total population. A fiscal rule adjusts government revenue to ensure that public debt eventually stabilises as a share of GDP, making government revenue as a share of GDP the preferred indicator of future fiscal pressure.

JEL classification codes: E17, E62, H68

Keywords: Fiscal projections, long-term model, long-term scenarios

**************

\section{Le cadre de projection fiscale dans les scénarios à long terme}

L'étude décrit le cadre fiscal utilisé dans les scénarios économiques à long terme, mettant l'emphase sur les révisions apportées depuis la version 2013 du modèle long terme. Les projections à long terme de dépenses publiques pour les pensions, la santé et les soins de longue durée sont maintenant séparées des autres dépenses primaires et viennent de travaux précédents à l'OCDE prenant en compte le vieillissement de la population et autres pressions sur les coûts. Les autres dépenses primaires sont maintenues constantes en termes réels sur une bases per capita, plutôt que constantes en proportion du PIB. Cette différence est importante dans le cas de projections fiscales à long terme car les revenus gouvernementaux sont sensibles au taux d'emploi, tandis que les dépenses sont liées à la population totale. Une règle fiscale ajuste les revenus gouvernementaux de façon à éventuellement stabiliser la dette publique en proportion du PIB, rendant le poids des revenus dans le PIB un bon indicateur des futures pressions fiscales.

Classification JEL: E17, E62, H68

Mots clefs : Projections fiscales, modèle long terme, scénarios à long terme 


\section{TABLE OF CONTENTS}

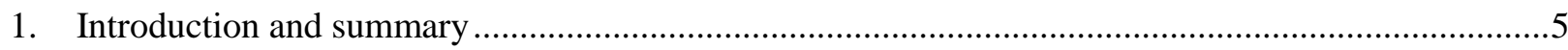

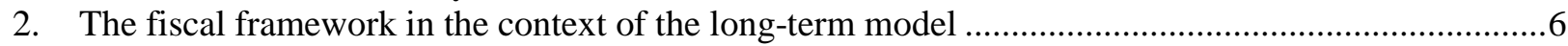

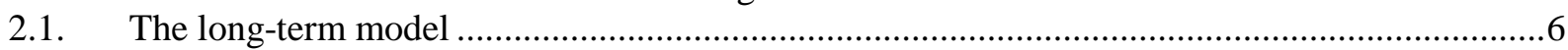

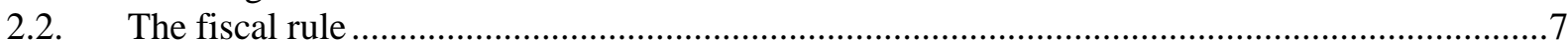

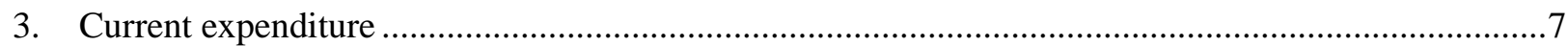

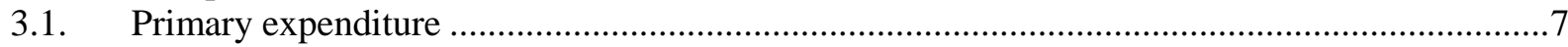

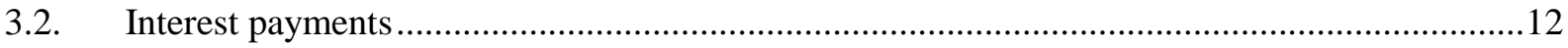

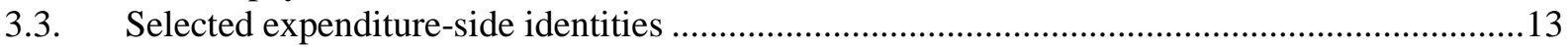

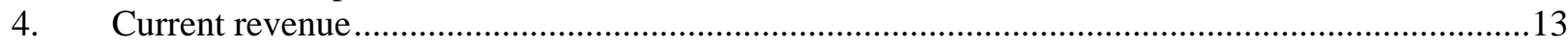

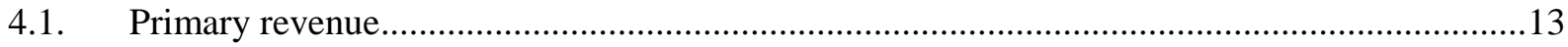

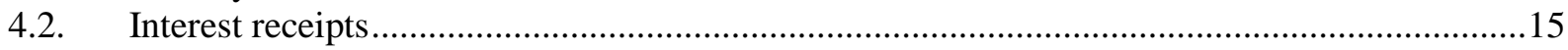

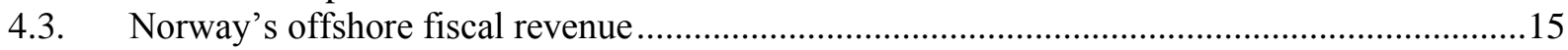

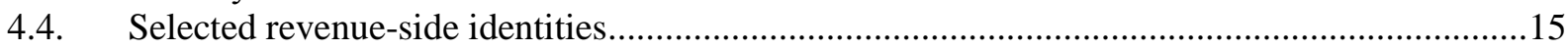

5. Net capital outlays of the government, saving and net lending .................................................. 16

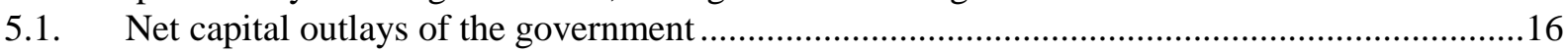

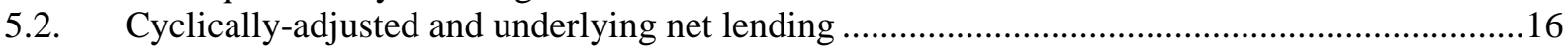

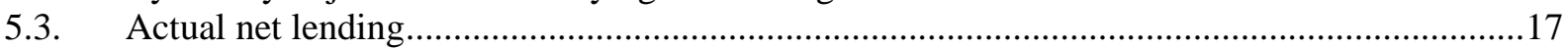

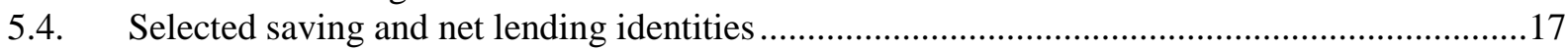

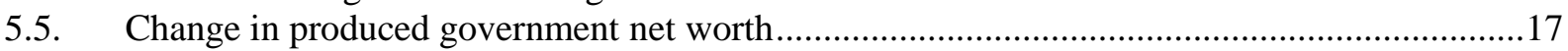

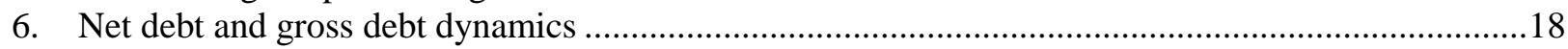

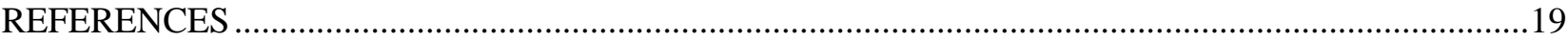

\section{Figures}

Figure 1. Projected change in demographically sensitive public expenditure between 2017 and 2060 ......8 Figure 2. Effect of 1 percentage point more employment growth from 2020 to 2025 ............................11

Figure 3. Projected change in primary government expenditure due to model revisions .........................11

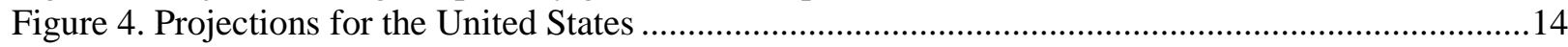


ECO/WKP(2017)72

\title{
THE FISCAL PROJECTION FRAMEWORK IN LONG-TERM SCENARIOS
}

\author{
by Yvan Guillemette and David Turner ${ }^{1}$
}

\section{1.}

\section{Introduction and summary}

1. Part of the usefulness of long-term scenarios is in assessing fiscal trends over the medium to long run. Questions around the impact of ageing on government spending, public debt sustainability, the sensitivity of fiscal positions to interest rate normalisation, the budgetary impacts of structural reforms, etc., all require a long-run perspective. To this end, the long-term model includes a fiscal block for 33 of the 46 countries in the model. ${ }^{2}$ The framework is largely similar to that of the OECD Economic Outlook. Its short-run projections provide the starting point for the long-run scenarios.

2. This note presents the fiscal block of the long-term model in detail, with some emphasis on improvements made since the 2013 vintage of the model (described in Appendix 10 of Johansson et al., 2013). Changes were made mostly to better account for the likely fiscal effects of demographic change. The main changes since the previous vintage of the model are the following:

- Reflecting a more general change to the underlying baseline assumptions, the long-term projections for public spending on pensions, health and long-term care are sourced from previous OECD work and are based on a continuation of current policies rather than assuming that future reforms will respond to emerging pressures. For health and long-term care expenditure, this means that the baseline projections are based on parameters reflecting historical experience, leading to what is described as a "cost pressure" scenario, instead of a "cost containment" scenario implying future policy reforms. Similarly, projections for pension expenditures incorporate future changes in pension eligibility which have already been legislated, but they do not assume any general linking of the pension age to life expectancy (unless this has been already legislated), as in previous vintages of the long-term scenarios. The advantages of the new approach are that it more clearly identifies the tensions which policy needs to address, and allows the effect of new policies to be more clearly identified in variant projections.

- For "other" primary expenditure (i.e. primary expenditure excluding health, long-term care or pensions), which on average across OECD countries account for about $23 \%$ of GDP, the baseline assumption is that such expenditures are maintained in real terms on a per capita basis, rather than remaining stable as a share of GDP. This difference is important for long-term fiscal projections, because maintaining expenditure on a per capita basis means that government finances are sensitive to the employment rate, as tax revenues follow employment whereas expenditure is linked to the total population. This in turn means that public finances are more sensitive to demographic developments and also means that structural reforms that boost employment have an additional benefit on the fiscal position.

1. The authors are with the OECD Economics Department's Macroeconomic Analysis Division. They would like to thank Boris Cournède, Peter Hoeller, Gabriel Machlica and Catherine Mann for comments and discussions; and Veronica Humi for editorial support (all from the OECD Economics Department).

2. Other countries, including most emerging-market economies, lack too much of the required fiscal indicators. 
- To ensure that government debt is stable as a share of GDP, tax rates are assumed to adjust, whereas previously the adjustment was split between primary expenditure and taxes. Changes in the tax burden thus provide a clear indicator of relative fiscal pressures across countries.

3. The note is structured as follows: after some background in Section 2, Sections 3 and 4 describe, respectively, the current expenditure and current revenue sides of the fiscal ledger, Section 5 explains the determination of net capital outlays and the calculation of saving and net lending, and Section 6 presents the identities linking fiscal flows with stocks of government financial liabilities and assets.

\section{The fiscal framework in the context of the long-term model}

4. Before presenting the fiscal block of the long-term model in detail, it is useful to first outline the broader model and its connections to the fiscal block, and to explain the rationale behind the assumed fiscal rule.

\subsection{The long-term model}

5. The long-term model uses as a starting point the short-run projections of the twice-yearly $O E C D$ Economic Outlook (EO). The EO includes historical estimates and short-run projections of potential output for each country based on a Cobb-Douglas production function with trend input components, namely trend labour efficiency, trend employment and the productive capital stock. This same production function sits at the core of the long-term model. Projections of trend labour efficiency are obtained by applying an estimated conditional convergence equation, which determines a country-specific long-run equilibrium based on a number of institutional and policy indicators (Guillemette et al., 2017). Projections of trend employment are done with a cohort-based model and use demographic projections from the European Commission and the United Nations (Cavalleri and Guillemette, 2017). Capital stock projections are based on a partially estimated equation that typically keeps the growth contribution of the capital stock relatively small in the baseline scenario but allows policy shocks in alternative simulations, including shocks to government investment (Guillemette et al., 2018). The rest of the model remains largely as described in Appendix 10 of Johansson et al. (2013): actual real GDP projections assume that any initial output gap closes gradually in the first few years of the projections; a Phillips-type equation determines the GDP deflator; and there are equations to project exchanges rates, interest rates, current accounts and a mechanism to ensure equilibrium between saving and investment at the global level.

6. The fiscal block connects to the rest of the model through several channels:

- The ratio of cyclically-adjusted government primary revenue to potential GDP is set by a fiscal rule (see the next subsection). The difference between actual and cyclically-adjusted revenue is then pinned down by the output gap (the percentage difference between actual and potential output) and a semi-elasticity parameter estimated in previous OECD work.

- The ratios of health, long-term care and pension expenditure to GDP are taken from preexisting work and are incorporated exogenously. But other primary expenditure is assumed to be kept constant in real per capita terms, so its ratio to GDP depends on the evolution of the trend employment to population ratio.

- Interest rates on government debt and assets are closely related to the model's short-run (three-month) and long-run (ten-year) interest rates. The short-term interest rate mainly depends on the output gap and the inflation rate (of the GDP deflator) in a Taylor-type equation. The equilibrium short-run interest rate in turn depends on the potential growth rate. The long-term 
interest rate is a forward convolution of future short-term interest rates plus a fixed term premium and a number of risk premiums that are described in Section 3.2.

\subsection{The fiscal rule}

7. In a long-term model solved over many decades, it is necessary to ensure that the debt-to-GDP ratio eventually stabilises, otherwise the model would not give reasonable results and may not even solve. However, picking the same target ratio for all countries (such as $60 \%$ of GDP as was done in the past) is problematic as the consequent fiscal adjustments can easily dominate the projections. Also, while a $60 \%$ of GDP target might make sense for European countries given existing treaties and commitments, many nonEuropean countries do not have an explicit debt target. There is also the thorny issue of whether the target should be set in net or gross terms given different financial asset positions across countries.

8. Instead, the baseline fiscal rule seeks to stabilise the debt ratio at its initial value (i.e. the projected value for the last year of the EO horizon) and does so by adjusting the ratio of cyclically-adjusted primary revenue to potential GDP, which can be interpreted as an overall tax rate on the economy (see Section 4.1 for the technical details). With such a rule, the debt target does not in itself dominate fiscal policy. Fiscal pressures from demographic and other sources will then be visible in what happens to the overall tax rate. Endogenising the tax rate in this way infringes somewhat on the 'no policy change' assumption that should characterise a baseline scenario, but at the same time, given that a minimal reasonable goal of fiscal policy should be to avoid an unstable debt path, this assumption can also reasonably be characterised as "neutral". The fiscal rule's set-up allows the target to be changed in alternative scenarios, including a possible consolidation scenario in which debt ratios would fall to some minimum threshold in all countries.

\section{Current expenditure}

9. On the expenditure side, the basic approach is to take exogenous projections of large primary expenditure items - namely health, long-term care and pensions - from previous OECD work and assume that other primary expenditure will evolve so as to provide a constant level of public service per capita. Interest expenses follow the evolution of public debt and interest rates.

\subsection{Primary expenditure}

\subsubsection{Explicit health, long-term care and pension expenditure projections}

10. In the 2013 vintage of the long-term model, the likely fiscal pressures associated with population ageing were not explicitly taken into account. Instead, they were calculated "off-model" and incorporated ex post into calculations of the change in the fiscal balance required to stabilise government debt (see Section 3.1.3). This revision incorporates explicit projections of public health and long-term care spending from de la Maisonneuve and Oliveira Martins (2013), as well as explicit public pension expenditure projections from OECD $(2015){ }^{3}$

11. The health spending projections of de la Maisonneuve and Oliveira Martins (2013) take account of both demographic and non-demographic drivers. Demographic drivers relate broadly to the age structure of the population and the evolution of its health status. Non-demographic drivers include income (and the

3. These sources have projections at five-year or greater intervals, so the missing years are filled using linear interpolation. In some cases, projections extend until 2050 or 2055 only. In such cases the last available projection is assumed to apply until 2060. 
responsiveness of health spending to it) and prices. Nevertheless, the combination of demographic and income effects fails to explain a large part of historical growth in public health-care expenditure. The residual is most likely related to technological progress and underlying health policies and institutions. In the projections, a real income elasticity of 0.8 is used and a common residual expenditure growth assumption of $1.7 \%$ per year is assumed in the cost-pressure scenario used for the baseline projection. On average across the OECD, public health spending is projected to increase by about $5 \frac{1}{2}$ percentage points of GDP by 2060 (Figure 1).

Figure 1. Projected change in demographically sensitive public expenditure between 2017 and 2060 Percentage points of GDP

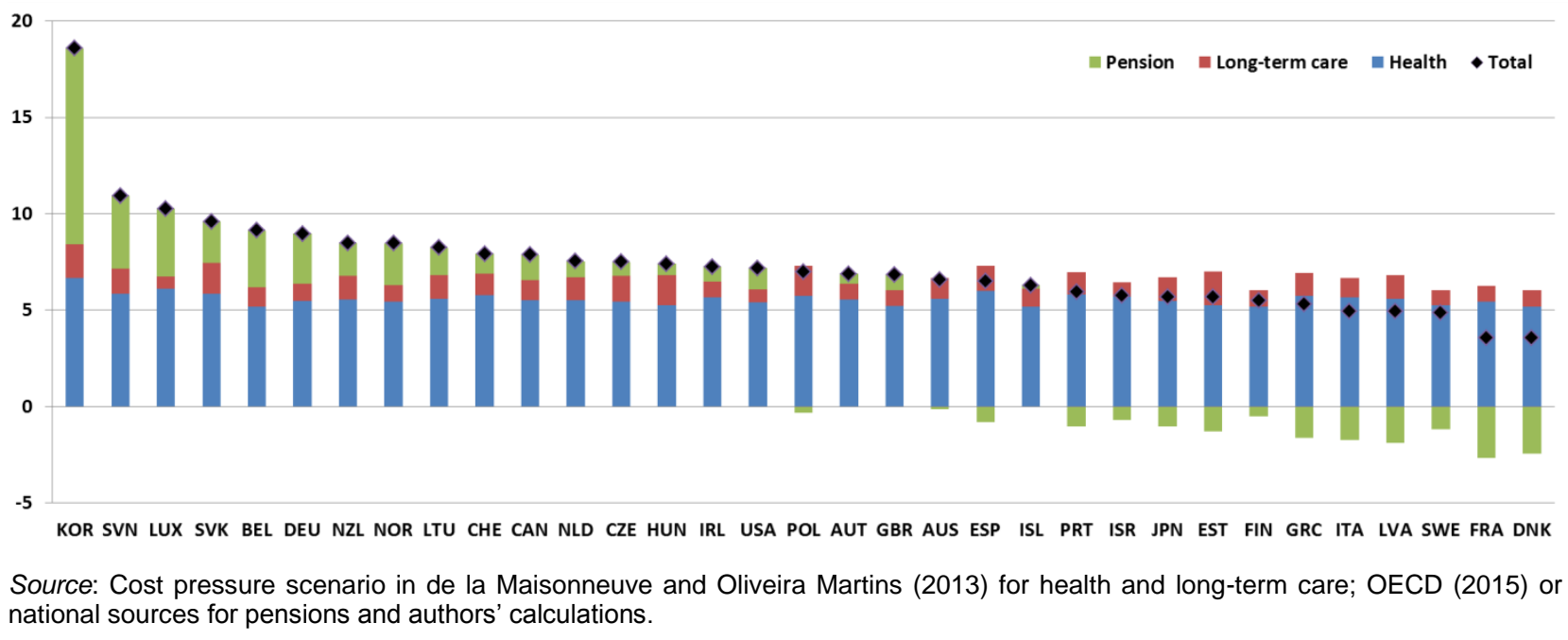

12. For the moment, the health spending projections are taken "as is" from de la Maisonneuve and Oliveira Martins (2013), but this source is becoming dated and its underlying economic assumptions cannot be perfectly coherent with the long-term baseline scenario other than by coincidence. The Employment, Labour and Social Affairs directorate has recently updated the projection methodology and is working on a tool to allow users to change some of the assumptions and generate alternative health spending projections (Marino et al., 2017). When new health expenditure projections become available, they shall replace the 2013 vintage in the long-term model and the aforementioned tool could help to align underlying economic projections as much as possible.

13. As for health care, two kinds of determinants drive the public long-term care expenditure projections of de la Maisonneuve and Oliveira Martins (2013), demographic and non-demographic. The demographic driver is related to the number of dependent people of old age in the population. The evolution of this factor depends on the evolution of life expectancy and health expenditure. The nondemographic drivers are related to income developments and changes in the demand for publicly financed long-term care services. Income is assumed to have a direct impact via increases in living standards (GDP per capita) and an indirect impact via cost-disease (relative productivity or Baumol) effects. Public longterm care spending is projected to increase by 1.1 percentage points of GDP by 2060 on average (Figure 1).

14. Pension spending projections from OECD (2015) include not only the projected increases in the number of beneficiaries, but also the future impacts of already-legislated measures such as retirement age increases, in-built pension system stabilisers, phasing out of early retirement provisions, changes to benefit 
formulas, etc. ${ }^{4}$ Public pension expenditure is projected to increase by 0.7 percentage points of GDP by 2060 on average (Figure 1).

15. Altogether, demographically-sensitive public spending categories are projected to absorb about 7 percentage points of GDP more by 2060 than now, and much more in some countries. ${ }^{5}$ Most of the crosscountry variation in projected spending changes relates to pension expenditure; there are eight countries (Korea, Slovenia, Luxembourg, Slovakia, Belgium, Germany, Norway and Greece) for which the increase in pension spending is projected to be 2 percentage points of GDP or more; on the other hand, it is striking that there are about a dozen OECD countries where pension reforms imply a modest decline in pension expenditure by 2060 .

\subsubsection{Residual primary expenditures}

16. The projections for health, long-term care and pension expenditures just described are incorporated exogenously into the long-term model. Primary expenditure excluding these three categories (henceforth residual primary expenditure) averages 23\% of GDP across OECD countries, ranging from $11 \%$ for Ireland to $33 \%$ for Finland. To project such expenditure, it is assumed that governments seek to maintain a constant level of service provision per capita. At the same time, it is assumed that prices of public sector services in this residual category follow wages in the rest of the economy. This implies that changes to the employment rate will be a major influence on the evolution of government residual primary expenditure as a share of GDP, as demonstrated by the following algebra.

17. Nominal government spending on residual primary expenditure $\left(E_{t}\right)$ can be expressed in terms of the volume of services provided $\left(V E_{t}\right)$ and their price index $\left(P E_{t}\right)$ :

$$
E_{t}=P E_{t} \cdot V E_{t}
$$

Expanding this definition with total population $\left(P O P_{t}\right)$ and employment $\left(L_{t}\right)$ :

$$
E_{t}=P E_{t} \cdot \frac{V E_{t}}{P O P_{t}} \cdot \frac{P O P_{t}}{L_{t}} \cdot L_{t}
$$

Dividing both sides of [2] by nominal GDP $\left(Y_{t}=P Y_{t} \cdot V Y_{t}\right)$, where $P Y_{t}$ is the GDP deflator and $V Y_{t}$ is real GDP, yields an expression for residual primary expenditure as a share of $\operatorname{GDP}\left(e_{t}\right)$ :

4. The source of the pension expenditure projections (the OECD's Pensions at a Glance 2015 publication) is not a primary source but simply collects information for OECD countries from other sources, namely the European Commission's 2015 Ageing Report for European countries (European Commission, 2015), Standard and Poor's Global Aging 2013 report for most non-European countries (Standard and Poor's, 2013), and a number of national sources. See the notes to Table 9.5 in OECD (2015) for more details. It is unfortunately unlikely that upcoming changes to pension rules are treated uniformely across these different sources. In addition, the most recent reforms (posterior to the primary sources' publication) are not included.

5. Other government spending items could also be considered demographically sensitive. However, with the possible exception of education, all are of second order importance when considering relative shares of government total expenditure. Education spending, in particular at the primary and secondary levels, is sensitive to demographics, but studies typically find only a negligible demographic effect (e.g. Robson, 2010 for the case of Canada). In addition, comparable projections of long-term education spending for a large number of countries are not currently available. 


$$
\frac{E_{t}}{Y_{t}}=e_{t}=\frac{P E_{t}}{P Y_{t}} \cdot \frac{V E_{t}}{P O P_{t}} \cdot \frac{P O P_{t}}{L_{t}} \cdot \frac{L_{t}}{V Y_{t}}
$$

Taking logs and differentiating both sides of [3] yields an expression for the growth rate of residual primary expenditure as a share of GDP:

$$
\Delta \log \left(e_{t}\right)=\Delta \log \left(\frac{P E_{t}}{P Y_{t}}\right)+\Delta \log \left(\frac{V E_{t}}{P O P_{t}}\right)+\Delta \log \left(\frac{P O P_{t}}{L_{t}}\right)+\Delta \log \left(\frac{L_{t}}{V Y_{t}}\right)
$$

The first term on the right-hand side of [4] is the growth rate of real prices for government services in the residual primary expenditure category. The second term is the growth rate of the volume of services per capita. The third term is the growth rate of the population-to-employment ratio. And the last term is the growth rate of the inverse of labour productivity (i.e. negative labour productivity growth).

18. Given that government expenditure are mostly made up of wages, and assuming both that wages in the government sector follow wages in the rest of the economy and, as is conventional, that real wages grow at the rate of labour productivity, ${ }^{6}$ then the first and last terms on the right-hand side of [4] cancel each other out. Furthermore, if government maintains a constant level of service provision per capita, then the second term on the right-hand side of [4] is zero. Only the third term remains, making it clear that residual primary spending as a share of GDP will change only to the extent that the population-toemployment ratio changes, so [4] becomes [5]. ${ }^{7}$ An increase in this ratio, as might be expected with population ageing, would raise public spending as a share of GDP.

$$
\Delta \log \left(e_{t}\right)=\Delta \log \left(\frac{P O P_{t}}{L_{t}}\right)
$$

19. On the other hand, reforms that boost employment would help to reduce the fiscal burden. For instance, in a simulation where the baseline employment-to-population share is $60 \%$ and government residual primary spending is $20 \%$ of GDP, a reform that boosts employment growth by one percentage point (above baseline) for 5 years would raise the employment-to-population share permanently by a little over 3.5 percentage points and thus lower public spending by close to 1.2 percentage points of GDP (Figure 2). This is not true of reforms that boost labour efficiency or capital intensity, however, because both would affect productivity, wages, government spending and nominal output in the same way in the long run, though not necessarily in the short to medium run.

6. In standard economic models the real wage is equal to the marginal product of labour. Also, with a CobbDouglas production function with fixed factors shares, such as the one used in the long-term model, the growth rate of the marginal product of labour is equal to that of labour productivity.

7. In practice, [5] is implemented in the model using trend components for output $\left(G D P V T R_{t}\right)$ and employment $\left(E T P T_{t}\right)$ and a cyclically-adjusted measure of residual primary spending $\left(Y P G X X A_{t}\right)$. The population and trend employment projections are explained in detail in Cavalleri and Guillemette (2017). 
Figure 2. Effect of 1 percentage point more employment growth from 2020 to 2025

A. Employment (\% of population)

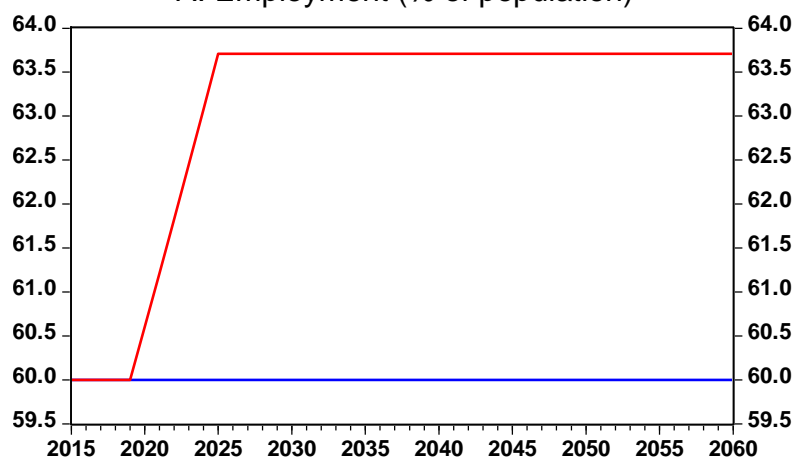

B. Residual primary expenditure (\% of GDP)

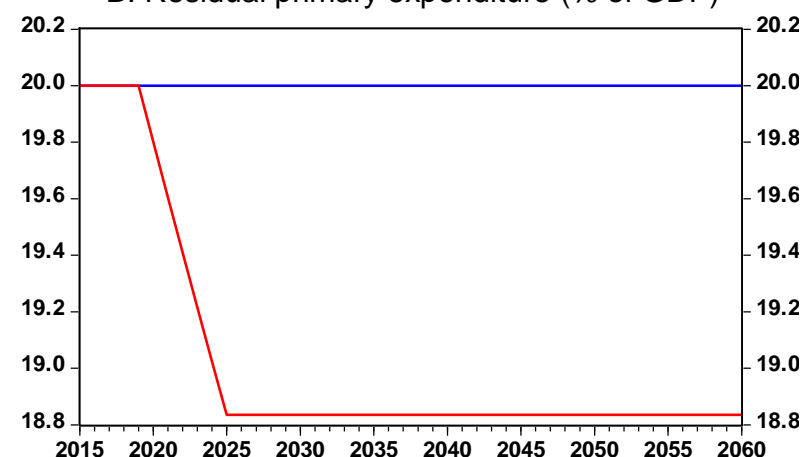

— Baseline — With positive shock to employment growth

\subsubsection{Impact of changes relative to 2013 model}

20. As mentioned previously, in the 2013 vintage of the long-term model, fiscal pressures associated with demographic change were not taken into account explicitly. The fiscal rule operated symmetrically on both the revenue and expenditure sides. Projected changes in primary expenditure were thus, by construction, half of any fiscal consolidation/easing implied by the fiscal rule. In countries necessitating neither consolidation nor easing, primary expenditure stayed constant as a share of GDP. Results were presented with the caveat that any fiscal consolidation required would need to be supplemented by the additional fiscal costs of ageing, with the latter shown in a separate table.

21. The incorporation of explicit health, long-term care and pension expenditure in the model puts upward pressure on primary expenditure as a share of GDP in all countries, although not to the same extent. The assumption of a constant level of service provision per capita for the residual primary spending category also puts upward pressure on primary expenditure in countries where the population-toemployment ratio is projected to increase, such as France (Figure 3, Panel A). This is the case in most, but not all, countries. For instance, residual primary expenditure is projected to decline slightly as a share of GDP in Israel, but not by enough to compensate for the projected increase in health, long-term care and pension expenditure (Figure 3, Panel B).

\section{Figure 3. Projected change in primary government expenditure from 2019 due to model revisions}

Percentage points of GDP

\section{A. France}

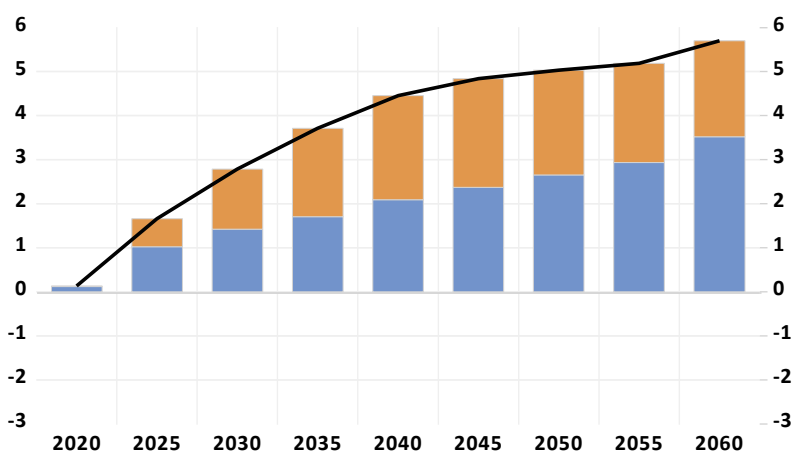

B. Israel

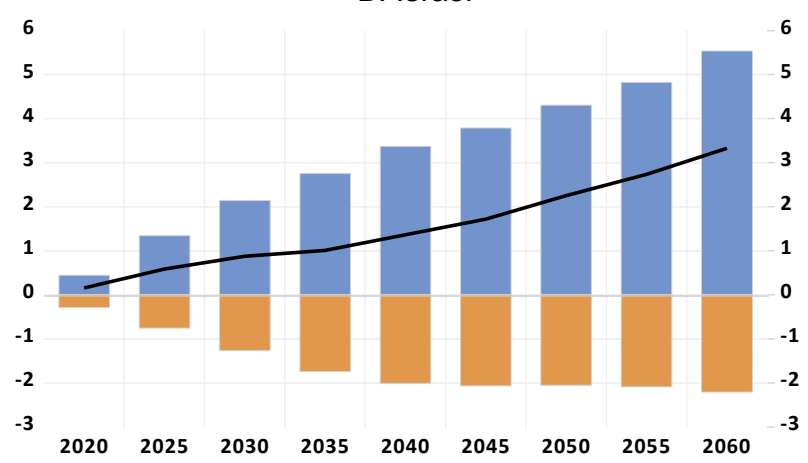

Source: de la Maisonneuve and Oliviera Martins (2013) and authors' calculations. 


\subsection{Interest payments}

22. Gross government interest payments $\left(G G I N T P_{t}\right)$ depend on the implicit average interest rate on outstanding government debt $\left(R A T E_{-} P_{t}\right)$ and on the stock of gross government financial liabilities $\left(G G F L_{t}\right)$ :

$$
G G I N T P_{t}=\frac{R A T E_{-} P_{t}}{100} \cdot G G F L_{t-1}
$$

For the last year of the historical period, [6] is inverted and used to compute $R A T E_{-} P_{t}$. Then, over the projection period, this implicit interest rate adjusts gradually to a weighted average of the short-term interest rate $\left(I R S_{t}\right)$ and the long-term interest rate $\left(I R L_{t}\right)$ as old debt is refinanced or new debt is issued:

$$
R A T E_{-} P_{t}=\left(1-R F S H_{t}\right) \cdot \frac{G G I N T P_{t-1}}{G G F L_{t-2}}+R F S H_{t} \cdot\left(0.25 \cdot I R S_{t}+0.75 \cdot I R L_{t}\right)
$$

where $\mathrm{RFSH}_{t}$ is the ratio of issuance to the outstanding stock of debt. For the last year of the historical period, $\mathrm{RFSH}_{t}$ is calibrated on the basis of the actual maturity structure of outstanding public debt. The longer the maturity structure, the lower this parameter and the slower the adjustment of the historical implicit rate to current market rates. For the projection period, the refinancing share is assumed to gradually converge to $20 \%$ in all countries following:

$$
R F S H_{t}=0.8 \cdot R_{F S H}+\Delta\left(\frac{G G F L_{t}}{G G F L_{t-1}}\right)+0.2 \cdot 0.2
$$

The middle term roughly accounts for new debt issuance related to changes in the fiscal balance or financial assets. A $20 \%$ long-term target for the refinancing share is selected because it is approximately the share of outstanding debt that is refinanced each year on average across OECD countries.

23. The determination of both short-run and long-run interest rates remains as described in Johansson et al. (2013), except for fiscal risk premia. As before, higher government debt levels are assumed to entail higher fiscal risk premia. For every percentage point that the debt ratio exceeds a threshold of $75 \%$ of GDP, the fiscal risk premium applied to long-term interest rates increases by 2 basis points, with an additional increase of 2 basis points for every percentage point that the debt ratio exceeds $125 \%$ of GDP. ${ }^{8}$ But an additional risk premium is related to any negative net international investment position, consistent with the findings of Lane and Milesi-Ferreti (2001), Rose (2010) and Turner and Spinelli (2013). For every percentage point increase in the ratio of net external debt to GDP, a premium of 2 basis points is applied to the long-term interest rate. ${ }^{9}$ For creditor countries (positive net international investment position), there is no corresponding discount, consistent with the findings of Turner and Spinelli (2013). An exception is made for the United States: given the reserve status of its currency, and despite a significantly negative net international investment position, no risk premium is applied.

8. See Appendix 10 in Johansson et al. (2013). The size of the premium is consistent with the findings of Égert (2010) and Laubach (2009). Japan is an exception to this rule: given the high proportion of government debt financed domestically, the fiscal risk premium is computed at one quarter the rate of other OECD countries.

9. In the model, projections of the net international investment position as a percentage of GDP is based on a simple law of motion that uses last period's value, the growth rate of GDP and this period's current account deficit as a percentage of GDP. It ignores the currency composition of assets and liabilities and therefore any valuation effects. 


\section{3. $\quad$ Selected expenditure-side identities}

24. With cyclically-adjusted residual primary spending $\left(Y P G X X A_{t}\right)$ set by [5] and other expenditure items entering the model exogenously, total cyclically-adjusted primary expenditure $\left(Y P G X A_{t}\right)$ is given by:

$$
Y P G X A_{t}=Y P G X X A_{t}+H E A L T H_{t}+L_{T} C_{t}+\text { PENSION }_{t}
$$

where $H_{E A L T H}, L T C_{t}$ and PENSION $_{t}$ are, respectively, the health, long-term care and pension expenditure projections mentioned previously and incorporated exogenously. Then, cyclically-adjusted

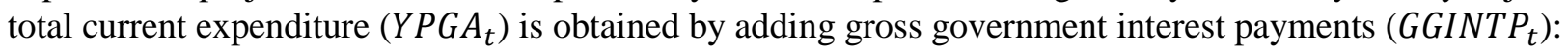

$$
Y P G A_{t}=Y P G X A_{t}+G G I N T P_{t}
$$

\section{Current revenue}

\subsection{Primary revenue}

25. As explained above, primary revenue is determined endogenously in the model by the fiscal rule so as to gradually stabilise the public debt ratio at a target level. In the baseline scenario this target will be the initial debt ratio. Consequently, primary revenue will change to correct any initial inconsistency between the fiscal balance and the target debt ratio. Over the projection period, it will also react to any change in projected expenditure.

26. The first part of the fiscal rule establishes an intermediate target for the overall budget balance as a share of GDP $\left(b_{t}^{*}\right)$ that is consistent with the target gross debt ratio $\left(d^{*}\right)$, taking into account the nominal growth rate of GDP $\left(g_{t}\right)$ and the target level of gross financial assets as a share of GDP $\left(a^{*}\right)$, which is usually assumed constant at the most recent observation (see Section 4.2):

$$
b_{t}^{*}=\frac{-g_{t}}{\left(1+g_{t}\right)}\left(d^{*}-a^{*}\right)
$$

This equation is derived from the conventional debt dynamics equation (see Rawdanowicz, 2012). In practice, to prevent sudden changes in this variable and ensure smoothness for other variables that depend on it, a 10-year forward moving average of nominal potential growth rates is used as $g_{t}$.

27. The second part of the fiscal rule establishes a target for cyclically-adjusted primary revenue as a share of potential GDP $\left(p r_{t}^{*}\right)$ as a function of the target budget balance given by [11]:

$$
p r_{t}^{*}=b_{t}^{*}+\frac{\left(Y P G A_{t}+C A P O G_{t}-G G I N T R_{t}\right)}{G D P T R_{t}}
$$

where $Y P G A_{t}$ is cyclically-adjusted government expenditure, $C A P O G_{t}$ is net capital outlays of the government, GGINTR $R_{t}$ is gross government interest receipts and $G D P T R_{t}$ is nominal potential output. This 
equation is derived from the identities linking the overall budget balance to its components, and makes the fiscal rule operate only on the revenue side of the budget. ${ }^{10}$

28. The third part of the fiscal rule defines the change in actual cyclically-adjusted primary revenue as a share of GDP $\left(p r_{t}\right)$ as a function of the target level defined in [12]:

$$
\Delta p r_{t}=\theta_{1}\left(p r_{t}^{*}-p r_{t-1}\right)+\theta_{2}\left(d_{t-1}-d^{*}\right)
$$

where $d_{t}$ is the current debt ratio, and $\theta_{1}$ and $\theta_{2}$ are parameters between zero and one affecting the speed at which the primary revenue and public debt ratios converge to their respective targets. Typically $\theta_{1}$ is set at 0.4 and $\theta_{2}$ at 0.05 . This set-up does not allow precise control on when targets are reached, as this also depends on initial values for the fiscal balance, the debt ratio, etc. Moreover, the fiscal rule can produce large year-to-year changes in primary revenue when initial values are far from their targets, implying large changes to tax policy. Especially when it comes to fiscal consolidation on the revenue side, political economy considerations limit how much can be done over a short period of time. So in practice, [13] includes a constraint to prevent structural primary revenue from rising by more than some fixed parameter, usually set at one percentage point of GDP per year.

29. The workings of the fiscal rule are illustrated for the case of the United States in Figure 4. At the starting point of the long-run projections in 2018 (dashed vertical line), primary revenue is a few percentage points of GDP lower than primary spending (panel A), and the debt ratio is on an upward trajectory (panel B). Meanwhile, primary expenditure is projected to increase by approximately nine percentage points of GDP between 2018 and 2060, with most of this increase attributable to health spending (see Figure 1). In response, the fiscal rule gradually raises primary revenue onto a path slightly above that of primary spending, the difference being necessary to cover net interest payments on the debt. This path is also consistent with setting the debt ratio on a gently declining trajectory toward the initial debt ratio, in this case about $110 \%$ of GDP.

Figure 4. Projections for the United States

Per cent of GDP

A. Primary government revenue and expenditure

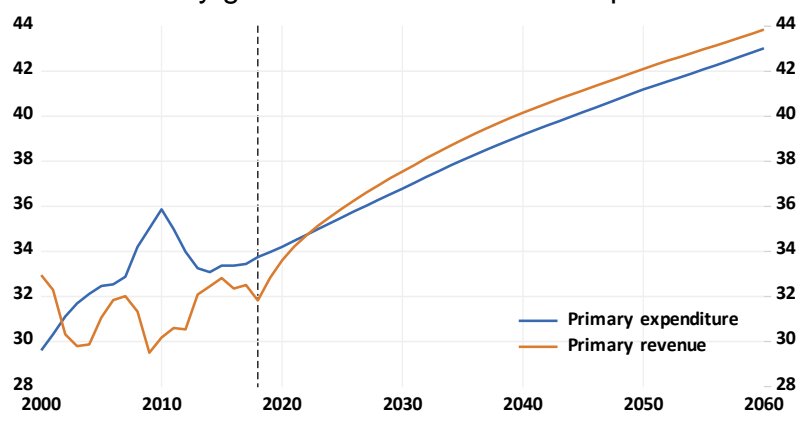

\section{B. Gross government liabilities}

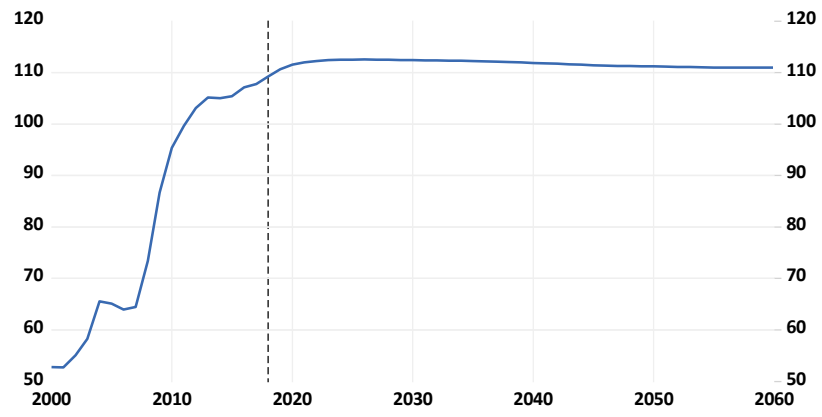

10. In the case of Norway, [12] is modified to account for offshore fiscal revenue, as these are excluded from cyclically-adjusted fiscal variables, where off_rev $v_{t}$ measures total offshore fiscal revenue as a share of GDP (see Section 4.3):

$$
p r_{t}^{*}=\left(b_{t}^{*}-o f f_{-} r e v_{t}\right)+\frac{\left(Y P G A_{t}+C A P O G_{t}-G_{G I N T R_{t}}\right)}{G D P T R_{t}}
$$




\subsection{Interest receipts}

30. Gross government interest receipts $\left(G G I N T R_{t}\right)$ depend on the implicit average interest rate on government financial assets $\left(R A T E_{-} R_{t}\right)$ and on the gross stock of government financial assets $\left(G F A_{t}\right)$ :

$$
G G I N T R_{t}=\frac{R A T E_{-} R_{t}}{100} \cdot G F A_{t-1}
$$

For the last year of the historical period, [14] is inverted to compute $R A T E_{-} R_{t}$. Then, over the projection period, government financial assets are assumed to remain a constant share of GDP, and the implicit rate of return on these assets keeps the same spread relative to the implicit rate on liabilities defined above $\left(R A T E_{-} P_{t}\right)$ as in the last historical period (here 2018), except for any change in the risk premium related to government or external debt $\left(R I S K P R E M_{t}\right)$ :

$$
R A T E_{-} R_{t}=R A T E_{-} P_{t}+\left(R A T E_{-} R_{2018}-R A T E_{-} P_{2018}\right)-\left(R I S K P R E M_{t}-R I S K P R E M_{2018}\right)
$$

This specification ensures that the evolution of the implicit rate of return on government financial assets follows the evolution of the rate paid on liabilities closely, but that any change to the risk premium on liabilities does not affect the return on assets.

\subsection{Norway's offshore fiscal revenue ${ }^{11}$}

31. In the case of Norway, offshore fiscal revenue as a share of GDP $\left(o f f_{-} r e v_{t}\right)$ is assumed to evolve following the net oil trade balance measured in barrels per year (OILNETEXPB $\left.B_{t}\right)$, the USD price of Brent crude per barrel $\left(W P B R E N T_{t}\right)$ and the exchange rate measured in USD per national currency $\left(\mathrm{EXCH}_{t}\right)$ :

$$
\Delta \log \left(\text { off_rev }_{t}\right)=\Delta \log \left(\frac{O I L N E T E X P B_{t} \cdot W P B R E N T_{t}}{E X C H_{t} \cdot G D P_{t}}\right)
$$

The volume of net oil trade is set exogenously. One possibility is to keep the last observation constant over the projection period. Another is to assume that net oil exports will decline slowly over the projection period as the resource depletes. The price of oil is also set exogenously and assumed to increase at a nominal rate of $3 \%$ per annum in the baseline scenario (corresponding to $1 \%$ increase in real US dollar terms given the assumed US inflation target of $2 \%$ ). The exchange rate is endogenous in the model as described in Appendix 10 of Johansson et al. (2013).

\subsection{Selected revenue-side identities}

32. Total cyclically-adjusted current primary revenue is given by:

$$
Y R G X A_{t}=p r_{t} \cdot G D P T R_{t}
$$

and total cyclically-adjusted current revenue by:

$$
Y R G A_{t}=Y R G X A_{t}+G G I N T R_{t}
$$

11. Although Norway is not the only country in the long-term model for which oil-related offshore revenue are important, it is the only one for which they are treated separately. Also, Saudi Arabia and Mexico do not have a fiscal block in the long-term model. 


\section{Net capital outlays of the government, saving and net lending}

33. Before calculating net lending and gross government saving, a few components related to capital spending are necessary. It is also necessary to move from cyclically-adjusted fiscal concepts to the actual national accounts definitions.

\subsection{Net capital outlays of the government}

34. Over the projection period, the change in government gross fixed capital formation in nominal terms $\left(I G A A_{t}\right)$ is related to the change in the volume of government investment $\left(I G V_{t}\right)$ and the investment deflator $\left(P I T_{t}\right)$ :

$$
\Delta \log \left(I G A A_{t}\right)=\Delta \log \left(I G V_{t}\right)+\Delta \log \left(P I T_{t}\right)
$$

This relationship makes the simplifying assumption that investment price inflation is the same in the government sector as in the private sector. Next, over the projection period, both capital transfers paid $\left(T K P G_{t}\right)$ and received $\left(T K T R G_{t}\right)$ are assumed to remain stable shares of potential GDP. Finally, growth in government consumption of fixed capital $\left(C F K G_{t}\right)$ is assumed to follow growth in both the volume of the public-sector capital stock $\left(K T P V_{-} G_{t}\right)$ and the investment price index just mentioned:

$$
\Delta \log \left(C F K G_{t}\right)=\Delta \log \left(K T P V_{-} G_{t}\right)+\Delta \log \left(P I T_{t}\right)
$$

This formulation implicitly assumes that the depreciation rate of the public-sector capital stock remains constant over the projection period. With the above-defined components, the net capital outlays of the government are obtained by identity:

$$
C A P O G_{t}=I G A A_{t}+T K P G_{t}-T K T R G_{t}-C F K G_{t}
$$

Linking public-sector investment and capital stock volumes to nominal capital outlays in the fiscal accounts ensures that shocks to government investment (in scenarios other than the baseline) will also have an impact on the fiscal side.

\subsection{Cyclically-adjusted and underlying net lending}

35. With the net capital outlays of the government and cyclically-adjusted current revenue and expenditure concepts as previously defined, cyclically-adjusted net lending $\left(N L G A_{t}\right)$ is computed as:

$$
N L G A_{t}=Y R G A_{t}-Y P G A_{t}-C A P O G_{t}
$$

The OECD Economic Outlook fiscal framework defines 'underlying' fiscal concepts, which are different from the 'cyclically-adjusted' concepts by the size of net fiscal one-offs $\left(N O O_{t}\right)$. This variable puts together one-offs related to net capital transfers as well as other exceptional items. Over the projection period, net one offs are assumed to decline to zero gradually following:

$$
N O O_{t}=\lambda N O O_{t-1}
$$

where the parameter $\lambda$ controls the speed of decay toward zero and is usually set at 0.7 . Underlying net lending $\left(N L G U_{t}\right)$ is then defined as:

$$
N L G U_{t}=N L G A_{t}-N O O_{t}
$$


Cyclically-adjusted net lending as a percentage of potential GDP $\left(N L G Q A_{t}\right)$, and the corresponding underlying concept $\left(N L G Q U_{t}\right)$ are obtained with:

$$
N L G Q\{A / U\}_{t}=\frac{N L G\{A / U\}_{t}}{G D P T R_{t}} \cdot 100
$$

\subsection{Actual net lending}

36. Net lending as a percentage of GDP $\left(N L G Q_{t}\right)$ is related to its cyclically-adjusted counterpart via:

$$
N L G Q_{t}=N L G Q A_{t}+\varepsilon \cdot G A P_{t}
$$

where $G A P_{t}$ is the output gap (expressed as a percentage of potential GDP) and and $\varepsilon$ is the overall semielasticity of the budget balance to the output gap. This semi-elasticity is country specific and taken from Price, Dang and Botev (2015). In most countries it is around 0.5, meaning that a one percentage point positive output gap raises the fiscal balance by about 0.5 percentage point of GDP relative to the structural balance. Again, there is an exception in the case of Norway to account for offshore revenue as explained previously:

$$
N L G Q_{t}=N L G Q A_{t}+\varepsilon \cdot G A P_{t}+o f f_{-} r e v_{t}
$$

Net lending $\left(N L G_{t}\right)$ is then recovered via the identity:

$$
N L G_{t}=\frac{N L G Q_{t}}{100} \cdot G D P_{t}
$$

\subsection{Selected saving and net lending identities}

37. The variables defined so far serve as bases for many other government saving and net lending identities. The primary balance $\left(N L G X_{t}\right)$, cyclically-adjusted primary balance $\left(N L G X A_{t}\right)$ and underlying primary balance $\left(N L G X U_{t}\right)$ are defined as:

$$
N L\{G X / G X A / G X U\}_{t}=N L\{G / G A / G U\}_{t}+G G I N T P_{t}-G G I N T R_{t}
$$

The primary balance as a percentage of $\operatorname{GDP}\left(N L G X Q_{t}\right)$ is obtained via the identity:

$$
N L G X Q_{t}=\frac{N L G X_{t}}{G D P_{t}} \cdot 100
$$

and similarly for the cyclically-adjusted primary balance as a percentage of potential GDP $\left(N L G X Q A_{t}\right)$ and the underlying balance as a percentage of potential GDP $\left(N L G X Q U_{t}\right)$, except that the denominator for the latter two is nominal potential GDP $\left(G D P T R_{t}\right)$. The change in the variable $N L G X Q U_{t}$ is usually how fiscal consolidation (when positive) or easing (when negative) is measured.

\subsection{Change in produced government net worth}

38. Following Bloch and Fall (2015), the change in produced government net worth can be calculated as an additional indicator of a government's financial health. This is normally defined as net government saving plus net capital transfers and measures the capacity of governments to finance their investments. In terms of the fiscal concepts already defined, the change in produced government net worth $\left(C P G N W_{t}\right)$ can be computed as: 


$$
C P G N W_{t}=N L G_{t}+I G A A_{t}-C F K G_{t}
$$

A negative value on this measure indicates that the financing for government investment needs to come from rising indebtedness.

\section{Net debt and gross debt dynamics}

39. The evolution of government net financial liabilities $\left(G N F L_{t}\right)$ follows the dynamic equation:

$$
\Delta G N F L_{t}=-N L G_{t}+S D G N F L_{t}
$$

where $S D G N F L_{t}$ is a statistical discrepancy that captures measurement errors as well as changes in the market value of outstanding liabilities. Over the projection period, this discrepancy is assumed to decline gradually to zero from its last value in the historical period following:

$$
S D G N F L_{t}=\varphi S D G N F L_{t-1}
$$

where $\varphi$ is a fixed parameter controlling the decay rate toward zero, usually set to 0.9 . Gross government financial liabilities $\left(G G F L_{t}\right)$ are obtained by adding to the net liabilities the government financial assets previously defined:

$$
G G F L_{t}=G N F L_{t}+G F A_{t}
$$

And both stock variables have counterparts expressed in percentage of GDP:

$$
G\{N / G\} F L Q_{t}=\frac{G\{N / G\} F L_{t}}{G D P_{t}} \cdot 100
$$


ECO/WKP(2017)72

\section{REFERENCES}

Bloch, D. and F. Fall (2015), "Government Debt Indicators: Understanding the Data", OECD Economics Department Working Papers, No. 1228, OECD Publishing, Paris. http://dx.doi.org/10.1787/5jrxv0ftbff2-en

Cavalleri, M. and Y. Guillemette (2017), "A Revised Approach to Trend Employment Projections in Long-Term Scenarios", OECD Economics Department Working Papers, No. 1384, OECD Publishing, Paris. http://dx.doi.org/10.1787/075f0153-en

de la Maisonneuve, C. and J. Oliveira Martins (2013), "A Projection Method for Public Health and LongTerm Care Expenditures”, OECD Economics Department Working Papers, No. 1048, OECD Publishing, Paris. DOI: http://dx.doi.org/10.1787/5k44v53w5w47-en

Égert, B. (2010), "Fiscal Policy Reaction to the Cycle in the OECD: Pro- or Counter-Cyclical?", OECD Economics Department Working Papers, No. 763, OECD Publishing, Paris. DOI: http://dx.doi.org/10.1787/5kmft7pthb27-en

European Commission (2015), The 2015 Ageing Report: Economic and budgetary projections for the 28 EU Member States (2013-2060), Publications Office of the European Union, Luxembourg.

Guillemette, Y. et al. (2017), "A revised Approach to Productivity Convergence in Long-Term Scenarios", OECD Economics Department Working Papers, No. 1385, OECD Publishing, Paris. http://dx.doi.org/10.1787/0b8947e3-en

Guillemette, Y., A. de Mauro and D. Turner (2018), "Saving, Investment and Current Account Projections in Long-Term Scenarios", OECD Economics Department Working Papers, forthcoming.

Johansson, Å. et al. (2013), "Long-Term Growth Scenarios", OECD Economics Department Working Papers, No. 1000, OECD Publishing, Paris. DOI: http://dx.doi.org/10.1787/5k4ddxpr2fmr-en

Lane, P.R. and G.M. Milesi-Ferreti (2001), "Long-Term Capital Movements", Centre for Economic Policy Research Discussion Papers, No. 2873.

Laubach, T. (2009), "New Evidence on the Interest Rate Effects of Budget Deficits and Debt", Journal of the European Economic Association, Vol. 7.

Marino, A. et al. (2017), "Future Trends in Health Care Expenditure: A Modelling Framework for CrossCountry Forecasts", OECD Health Working Papers, No. 95, OECD Publishing, Paris. DOI: http://dx.doi.org/10.1787/247995bb-en

OECD (2015), Pensions at a Glance 2015: OECD and G20 indicators, OECD Publishing, Paris. DOI: http://dx.doi.org/10.1787/pension_glance-2015-en 
Price, R., T. Dang and J. Botev (2015), "Adjusting Fiscal Balances for the Business Cycle: New Tax and Expenditure Elasticity Estimates for OECD Countries", OECD Economics Department Working Papers, No. 1275, OECD Publishing, Paris. DOI: http://dx.doi.org/10.1787/5jrp1g3282d7-en

Rawdanowicz, Ł. (2012), “Choosing the Pace of Fiscal Consolidation”, OECD Economics Department Working Papers, No. 992, OECD Publishing, Paris. DOI: http://dx.doi.org/10.1787/5k92n2xg106gen

Robson, W.B.P. (2010), “The Glacier Grinds Closer: How Demographics Will Change Canada's Fiscal Landscape", e-brief, No. 106, C.D. Howe Institute, Toronto.

https://www.cdhowe.org/sites/default/files/attachments/research_papers/mixed//ebrief_106_Robson. pdf

Rose, D. (2010), “The Influence of Foreign Assets and Liabilities on Real Interest Rates", Institute of Policy Studies Working Papers, No. 10/09.

Standard and Poor's (2013), Global Aging 2013: Rising To The Challenge, Standard and Poor's Ratings Services.

Turner, D. and F. Spinelli (2013), "The Effect of Government Debt, External Debt and their Interaction on OECD interest rates", OECD Economics Department Working Papers, No. 1103, OECD Publishing, Paris. DOI: http://dx.doi.org/10.1787/5k3ttg5c0026-en 